\title{
Scenarios of Health Engagement Experiences and Health Justice in Rural Libraries
}

Bharat Mehra, University of Alabama, USA

Everette Scott Sikes, University of Tennessee, USA

Vandana Singh, University of Tennessee, USA

\begin{abstract}
This article documents scenarios or narratives of health engagement experiences in rural libraries based on qualitative analysis of feedback collected from 15 rural librarians in the Southern and Central Appalachian (SCA) region during semi-structured interviews conducted in 2017-2018. The article focuses on respondents' perspectives of the "aboutness" of their health-related engagement, collaborating partners, encountered challenges, and resulting outcomes. Scenarios were documented in broader interviews that focused on specific health activities and community engagement in 11 domains, including agriculture, diversity, economy, education, environment, government, health, law, manufacturing, social welfare, and other. The research forms part of a planning grant entitled “Assessment of Rural Library Professionals' Role in Community Engagement in the Southern and Central Appalachian Region: Mobilization from Change Agents to Community Anchors (CA2CA@SCA-RL)" awarded by the Institute of Museum and Library Services to the University of Tennessee, sub-contracted to the University of Alabama this year (July 2017 - June 2019). Scenarios provide a taxonomic classification of health-related programs relevant to the region and a framework of practice related to their implementation. As a health justice tool, they also challenge the hegemonic imagination of mainstream American society, news media, and popular culture that has only presented the SCA rural belt in deficit light. The article becomes a counter-point to these past unfair and marginalizing representations in its constructive asset recognition of the SCA rural librarians' positive examples of health-related experiences. It spotlights the "invisible" of SCA librarians' individual/community empowerment as change agents making an impact on the lives of their rural residents.
\end{abstract}

Keywords: community engagement; health justice; rural libraries; scenarios; Southern and Central Appalachia

Publication Type: research article

\section{Introduction}

T his article documents scenarios or narratives of health engagement experiences in rural libraries based on qualitative analysis of feedback collected from 15 rural $^{1}$ librarians during semi-structured interviews conducted in 2017-2018. The research forms part of a larger planning grant entitled “Assessment of Rural Library Professionals' Role in Community Engagement in the Southern and Central Appalachian Region: Mobilization from Change Agents to Community Anchors" (CA2CA@SCA-RL) ${ }^{2}$ awarded by the Institute of Museum and Library Services' Laura Bush 21 $1^{\text {st }}$ Century Librarian-FY 2017 Guidelines (Community Anchors Project Category) to the School of Information Sciences at the University of Tennessee, sub-contracted

The International Journal of Information, Diversity, \& Inclusion, 3(3), 2019

ISSN 2574-3430, jps.library.utoronto.ca/index.php/ijidi/index

DOI: $10.33137 /$ ijidi.v3i3.32963 
to the School of Library and Information Studies at the University of Alabama this year (July 2017 - June 2019) (Mehra, Singh, \& Sikes, 2018). The article focuses on the respondents' perspectives of the "aboutness" of their health engagement activities, collaborating partners, encountered challenges specific to the regions, and resulting outcomes. "Aboutness" is defined as an overview or general descriptive details about the information projects, programs, and initiatives getting discussed. The scenarios were documented in broader interview conversations that focused on specific health experiences and community engagement in 11 varied domains: agriculture, diversity, economy, education, environment, government/public policy, health, law and justice, manufacturing/industry, social welfare, and other. Scenarios/stories of experience shared by rural librarians helped to develop a taxonomic classification of health-related projects and programs relevant to the region and a framework of practice in terms of partners-challengesoutcomes related to their implementation and operationalization.

\section{Health and Rural Context}

As stewards of information and advocates of literacy, public libraries have long fostered health information literacy through educational programming, partnerships and collaboration with community health organizations, and outreach services to specific user populations, particularly those that are considered underserved or vulnerable (Barr-Walker, 2016; Mehra, 2014). For those who lack computers or internet technologies at home, public libraries facilitate improved access to health information and offer resources to community members in their provision of computer workstations and $\mathrm{Wi}-\mathrm{Fi}$ (Rubenstein, 2017). In a time when people are more directly involved in decisions about their health care and in finding information related to health issues, libraries thus play an important and critical role for consumers who lack access to information resources (Prechtel, 2008; Zionts, Apter, Kuchta, \& Greenhouse, 2010). Public libraries are considered to be trustworthy information resources that greatly contribute to the ability of users to find needed health information (Baker, Spang, \& Gogolowski, 1998; Harris, Henwood, Marshall, \& Burdett, 2010; Horrigan, 2015).

Public libraries serve as one of the few important resource places for meeting unique rural health literacy needs of those geographically-dispersed users who do not own computers or have internet access in their homes and where availability of health service providers is limited (Lukenbill \& Immroth, 2009; Stanton, 2017; Temple, 2017). Borman and McKenzie (2005) noted that, in rural areas, healthcare providers regularly referred patients to the library for further information about their health and that public libraries were one of the few places where people in rural communities could go to find such information. According to Rubenstein (2016a), "There is often scant access to the internet in rural and disadvantaged communities due to lack of funding for high-speed connections, along with few other places to obtain information" (p. 332).

A study of people who utilized the library to find health information found these users often lacked home internet access and, compared to others, were less educated, had lower incomes, were more likely to be retired or unemployed, and had limited or no health insurance (Kwon \& Kim, 2009). Real, McDermott, Bertot, and Jaeger (2015) noted that consumers who signed up for the Affordable Care Act (ACA) through a public library were more often disadvantaged in terms of the digital divide, indicating the crucial role libraries played in providing vital health information to vulnerable and marginalized groups. Public libraries have provided information and support found to be critical to efforts to promote health among underserved populations, particularly low-income families, users in rural areas, those with disabilities, and elder persons (Eng et al., 1998). This is particularly true in the Appalachian region, which is largely rural and

The International Journal of Information, Diversity, \& Inclusion, 3(3), 2019

ISSN 2574-3430, jps.library.utoronto.ca/index.php/ijidi/index

DOI: $10.33137 /$ ijidi.v3i3.32963 
has historically been recognized for its socioeconomic challenges and for having a high proportion of residents who are considered disadvantaged (Appalachian Regional Commission, n.d.a; Eller, 2008; Mehra, Bishop, \& Partee II, 2017a, 2017b, 2017c). Studies have shown evidence that health disparities between the region and the rest of the country have grown and that the association between poverty and lower life expectancy in Appalachia is stronger than in other regions of the U.S. (Gutschall, Thompson, \& Lawrence, 2018; Singh, Kogan, \& Slifkin, 2017).

While public libraries, as trusted sources in their communities, are able to both promote health information literacy and provide users with access to health information, Rubenstein (2016b) contended that little research has explored the ways libraries address health literacy as a matter of public good or how they work to close health literacy gaps. Mehra, Albright, and Rioux (2006) advocated for a social justice perspective in the practice of information professions and offered a framework for information science research that was focused on tangible outcomes and the facilitation of change in the lives of marginalized populations. The researchers utilized examples from qualitative studies, two of which represented an information service related to the provision of health information in order to meet the specific needs of an underserved group. Behringer et al. (2007) considered health disparities in the Appalachian region and also called for a perspective of social justice that utilizes place-based and collaborative action to raise the level of awareness of communities to healthcare challenges and encouraged local credible sources such as public libraries to become proactive in the dissemination of health information. The researchers drew particular attention to the "real access barriers faced by rural residents that should be acknowledged and addressed in regional health promotion programs and interventions" (p. 45) and suggested that solutions would require coordinated efforts by community members.

Flaherty and Miller (2016) noted the significant disadvantages for rural residents in regard to access to health information and health promotion activities and argued that, while public libraries do provide health information, opportunities exist for broader community engagement related to health. Flaherty (2018) later called for rural public libraries to promote and support active, healthy lifestyles and to collaborate with other professionals and community groups to introduce community health initiatives. Librarians can realize a host of unique opportunities that such collaborations may offer for positive changes in the communities they serve (Flaherty 2018; Flaherty \& Miller, 2016; Jaeger, Wentz, \& Bertot, 2015).

Flaherty and Grier (2014) studied health information practices that brought together medical and public library practitioners through a collaborative outreach project in which consumer health librarians were embedded in public libraries. The researchers found a positive effect on staff knowledge and awareness of consumer health resources, on user expectations, and on the provision of health information in general.

Malachowski (2014) explored community health initiatives that occurred in public libraries and found examples of several, including health screenings, vaccine clinics, health fairs, resource and support meetings, health insurance enrollment assistance, health-related programming, and even on-site healthcare professionals. A shared aspect of all initiatives was a working partnership with local health officials and practitioners. Woodson, Timm, and Jones (2011) provided an overview of a successful project by a library to serve its local community. Librarians created a web portal focused on children's health that provided information through appropriate games and activities. Story hours in the public library also made use of stories and follow-up activities selected by faculty members at a nearby university medical library.

The International Journal of Information, Diversity, \& Inclusion, 3(3), 2019

ISSN 2574-3430, jps.library.utoronto.ca/index.php/ijidi/index

DOI: $10.33137 /$ ijidi.v3i3.32963 
For those users who have access to health information, Flaherty (2013) saw a need to understand the best ways to provide guidance and strategies for the evaluation of information: "With an ever-increasing emphasis on patient/consumer responsibility for health and an ever-escalating amount of information available, individuals are in need of support when it comes to utilizing health information resources" (p. 164). The author noted that widening access to online health information resources, even if only available through a local public library, meant that users are in need of support, education, and guidance in utilizing such resources. Eysenbach and Köhler (2002) echoed this issue, stating that once users encounter health information, they may not have the knowledge or ability to evaluate its authority and quality. Additional research has considered that access to information does not necessarily mean that the information is comprehended. Language barriers and difficulties in interpreting and evaluating health information present further elements of the issue of accessibility for underserved and vulnerable user populations (Chobot 2004; Gillaspy 2005; Oelschlegel, Earl, Taylor, \& Muenchen, 2009).

Flaherty (2016) stated that public libraries are uniquely suited to assist community members in searching, finding, and evaluating available health information. The author noted a dearth of research assessing the quality of information users receive when they seek help with health questions at a public library and that there appeared to be no standardization regarding the manner in which health queries were handled in most libraries. A further study found this to also be the case for print materials or collection development policies related to health information (Flaherty \& Kaplan, 2016). According to Rubenstein (2017), in addition to the problem of users who often lack the knowledge or ability to both find and critically evaluate information, librarians themselves may have limited proficiency or experience in assisting users with information needs related to health.

Rubenstein (2012) noted that public demands and expectations for health information had grown considerably in past years. Public libraries "have struggled to interpret their place within this burst of enthusiasm that has grown exponentially as the general population demands increased access to information as a way of taking control of health concerns" (p. 202). The researcher further stated that libraries can meet these changing information needs especially through collaboration with community partners and through the continued focus on full accessibility of online health resources for their users. While librarian education, budgets for collection development, the health information literacy gap, issues of diversity, and community partnerships all pose challenges for libraries in providing health information, such concerns are not new and creative solutions do exist.

\section{SCA Context and Rural Libraries}

The Southern and Central Appalachian ${ }^{3}$ (SCA) region, including its rural areas, form part of the 205,000-square mile area in 13 states around the Appalachian Mountains (Appalachian Regional Commission (ARC), 2015a). For the period October 1, 2017 through September 30, 2018, based on an index-based county economic classification system, an assessment of the region's economic status indicated that out of its total 420 designated counties, 84 were distressed, 115 were atrisk with 231 distressed areas, and 208 were transitional with 651 distressed areas (ARC, 2017a). In comparison to the nation's $20 \%$ rural population, $42 \%$ of Appalachian residents live in rural areas, with a $16.7 \%$ poverty rate in the region with its 93 high-poverty counties (that have poverty rates more than 1.5 times the U.S. average) during the 2012-2016 period (ARC, n.d.a). The U.S. Census Bureau (2012) identified two-thirds of the Appalachian counties with populations of less than 50,000 people and 125 counties with fewer than 20,000 inhabitants. In the $21^{\text {st }}$ century,

The International Journal of Information, Diversity, \& Inclusion, 3(3), 2019

ISSN 2574-3430, jps.library.utoronto.ca/index.php/ijidi/index

DOI: $10.33137 /$ ijidi.v3i3.32963 
with federal funding support rural populations in these areas are advancing towards economic recovery and community development to overcome some of their historically debilitating circumstances (e.g., slow financial growth, unemployment, illiteracy, information poverty, and insufficient telecommunications substructure, amongst others) (ARC, n.d.b; Catte, 2018; Mehra, Black, Singh, \& Nolt, 2011; Williams, 2003).

The ARC's (2017b) Performance and Accountability Report: Fiscal Year 2016 identifies an allocation of $\$ 109.2$ million to fund 470 area development projects that further the five goals of ARC's 2016-2020 strategic plan that focus on economic opportunities, ready workforce, critical infrastructure, natural and cultural assets, and leadership and community capacity. As change agents and community anchors, rural libraries in the region are beginning to play a significant role in operationalizing these goals and bridging intersections between these agendas towards: 1) Community capacity and skill development; 2) Leverage of heritage asset management in community and economic growth; 3) Development of technological infrastructures in terms of their socio-technical dimensions; 4) Education, health, and knowledge management; and 5) Investment in entrepreneurial and business enhancement strategies (Mehra \& Singh, 2014, 2017; Swan, Grimes, \& Owens, 2013).

This article provides a glimpse of the "invisible" in the scenarios/stories of the personal and community empowerment of the SCA rural librarians who are serving as change agents in making a meaningful impact on the individual lives of their rural residents living in their traditionally debilitating communities, empowering them in the process (Mehra, Singh, Hollenbach, \& Partee II, 2017; U. S. Environmental Protection Agency, 2017). According to Page and Scott (2001), a change agent "facilitates a 'bedding down' of new practices within organizations" (p. 530), develops skills they learn and pass on to others based on "changed work practices...and changes in their relationship to colleagues" (p. 548), and an "ability to take understandings arising in one 'world'" (p. 548) to use them for instigating change in another. In addition, these health-related scenarios/stories of experience represent library-and-community-wide empowerment that is subversive in that it challenges the hegemonic imagination of mainstream American society, news media, and the popular culture that has only presented deficit patterns of representations of the rural areas and of the SCA region (Hamby, 2018; Mehra, 2017).

This article becomes a counter-point to these past unfair and marginalizing representations in its constructive asset recognition of the SCA rural librarians' positive examples of health-related experiences (PDA Inc., et al., 2017). The qualitative pilot study provides a significant access point of granular data collection. Research methods developed in the CA2CA@SCA-RL are expanding similar qualitative approaches with a larger pool of SCA rural library professionals as well as use of additional quantitative survey-based strategies to document the rural librarians' perspectives in the region about their future directions of growth and application. Methods will be replicated in the future for other rural areas as well as the larger Appalachian region.

\section{Health Justice Imperative}

The documented scenarios/stories of health engagement experiences of rural librarians are intimately tied to issues of health justice on many levels; the following are a few salient aspects of note. First, rural libraries around the country, including in the SCA region, have long been overlooked in the library and information professions (Mehra, Bishop, \& Partee II, 2017a; Real, Bertot, \& Jaeger, 2014). The narrative stories of the SCA rural librarians' health-related experiences described in this article present a glimpse of an "untold" picture of rural library

The International Journal of Information, Diversity, \& Inclusion, 3(3), 2019

ISSN 2574-3430, jps.library.utoronto.ca/index.php/ijidi/index

DOI: $10.33137 /$ ijidi.v3i3.32963 
engagement with external stakeholders to overcome challenges and achieve tangible outcomes in spite of the unique conditions and limited resources they had available at their disposal (ARC, 2015b; Mehra, Bishop, \& Partee II, 2018). However, what dimensions of these many healthrelated scenarios from rural libraries have been heard in public forums within (and beyond) professional associations and organizations of library and information science (LIS) is debatable (Kruger, et al., 2012). They are often conspicuously missing as one encounters a "professional cacophony" focusing only around libraries in the metropolitan areas and those located in the Northeast, Northwest and/or Midwestern belts of the country, marginalizing others that are outside these geographic bastions of privilege and high visibility in LIS discourse in research, education, or the practitioner's world (Mehra, Bishop, \& Partee II, 2017b; Real \& Rose, 2017).

\section{Research Methods}

The following is a brief discussion of the use of scenarios as a methodological tool in this research and the data collection and data analysis reported in the article.

\section{Scenario Use and "Voice"}

For many years, scenarios as representative of typical user-centered experiences have found significant application in usability testing and evaluation in software development and theoretical and applied systems design (Carroll, 1995). Scenarios provided real or imagined stories to engineers, designers, and computer scientists of actors other than themselves, of their unfamiliar activities that were unknown to these "experts," and elements of the user-oriented processes towards achieving certain purposes or agendas that had possibilities of improving technological and system infrastructures (Carroll, 2003). Unfortunately, scenario use as an instrument of social justice research to further concerns of equality/equity, fairness, justice, and empowerment of "invisible" perspectives and points of view has been used in very few studies (Mehra, 2015; Mehra \& Rioux, 2016). For example, Mehra, Bishop, Bazzell, and Smith (2002) crafted scenarios as tools in participatory action research for studying health information seeking and use by African-American women across the digital divide based on intersections of race/ethnicity and gender (Helsper, 2010; Zickuhr \& Smith, 2012). Andrews, Dyson, and Wishart (2015) employed scenario-based learning to advance ethics frameworks in support of educational research in the context of mobile technologies. In furthering this stream of tradition in previous work, the article's use of scenarios provides the authors an opportunity to represent and recognize the experiences and perspectives of a hidden category of professionals in our midst, namely rural librarians from an oft stigmatized geographical region of the Southern and Central Appalachia (Mehra, Bishop, \& Partee II, 2016, 2017a, 2017b, 2017c). Scenarios became a mechanism in this research to provide "voice" to the SCA rural librarians in terms of what Belenky, Clinchy, Goldberger, and Tarule's (1986) consider as unheard and inter-personal connected ways of knowing and learning, though silenced owing to imposed social and cultural dogma and hegemony (Campbell, 2016). This article's purpose of scenario-building as the medium of the "voice" of the marginalized rural librarians highlights themes in a shared experience of the collective with potential for action to promote change from an imbalanced status quo within the LIS professions (Moraga \& Anzaldúa, 2015).

\section{Data Collection}

Personal interviews were conducted with 15 rural library professionals throughout the select SCA region to provide input about their experiences in community engagement while collaborating

The International Journal of Information, Diversity, \& Inclusion, 3(3), 2019

ISSN 2574-3430, jps.library.utoronto.ca/index.php/ijidi/index

DOI: $10.33137 /$ ijidi.v3i3.32963 
with external partners. A mix of intersecting factors related to the individual interviewee characteristics (e.g., number of years in professional service, professional role/title) and the contextual setting traits (e.g., size and scale of library and community, state and county, geographical and environmental conditions) were considered while narrowing representative regions of the interviewees. The personalized conversations between the intervieweeinterviewer were one-on-one and implemented via Zoom, an online cloud platform that provides real-time remote conferencing services and web-based meetings (Zoom Video Communications, 2019). The recorded discussions took place through the use of built-in computer microphones without use of the video component owing to limitations of broadband width and stability of connectivity in rural environments (Federal Communications Commission, 2012). The research team elicited assistance of select state library data coordinators, grant partners, and 11 grant advisory board members to encourage rural library director and staff participation. Grant partners included: 1) Blount County Public Library, TN (http://www.blountlibrary.org/); 2) Clinch River Regional Library, TN (http://sos.tn.gov/products/tsla/clinch-river-regional-library); 3) Library of Virginia, VI (http://www.lva.virginia.gov/); 4) Sevier County Public Library System, TN (https://www.facebook.com/SevierCountyPublicLibrarySystem/); and 5) Wiggins Memorial Library, NC (https://lib.campbell.edu/). Library staff in rural communities had a vested interest in sharing their successes and challenges with the greater professional community. The potential of interview findings to help justify future rural library funding and assist other information agencies in community engagement has been incentive enough to encourage participation in past studies. A convenience sample was generated using snowball sampling - earlier interviewees from rural libraries were asked to identify individuals who might be potentially interested to provide relevant and valid interview datasets. Professional networks of the research team provided leads to some participants until saturation sufficiency was achieved (Charmaz, 2006; Dey, 1999). Determining saturation at a sufficient level involved considering three aspects: 1 ) Occurrence of redundancy and replication of themes and categories in interviewee responses; 2) Development of well-considered pilot research experiences (e.g., interview process, testing of data collection instrument, practice of data analysis procedures) that could be applied to a larger SCA rural librarian sample-set with use of additional qualitative methods (e.g., focus groups) (Mehra, Sikes, \& Singh, 2018); 3) A diverse though limited selection of SCA representative regions intertwined with interviewee demographic characteristics. The essential criteria for interviewee selection was for potential participants to be a rural library paid staff member (e.g., library assistants, managers/directors, paraprofessionals) from a county in the SCA region. The research team intentionally included individuals who had played some role in decision-making in whatever capacity in their rural library to gather relevant, valid, and meaningful feedback regarding planning, developing, and implementing community engagement initiatives. All 15 interviewees were Caucasian women except one who was Hispanic/Latino. Table 1 summarizes participant demographics and relevant contextual information (e.g., professional titles).

The researchers created a semi-structured guide consisting of a series of open-ended questions to prompt participants to identify ways their rural library had collaborated, partnered, or engaged with external community stakeholders in the domain of health and others during the past five years. Table 2 provides the names and definitions of the twelve domains. The interview guide is available at URL: http://heramac.cci.utk.edu/INSC560Sp18/CA2CA@SCA$\mathrm{RL}$ InterviewGuide.pdf. As the interview guide shows, the 12 domains were areas that were specifically and deliberately covered in the interviews, with the "Other" category providing interviewees opportunities to share about initiatives and programming on topics that had not already been addressed. For the domain of health, the following are sample questions used during the interviews:

The International Journal of Information, Diversity, \& Inclusion, 3(3), 2019

ISSN 2574-3430, jps. library.utoronto.ca/index.php/ijidi/index

DOI: $10.33137 /$ ijidi.v3i3.32963 
- Describe up to THREE initiatives (virtual or in-person) related to issues of health through which your library assisted or engaged with external community stakeholders during the past five years.

- For each initiative, list the collaborating external community stakeholders (e.g., nonprofits organizations, institutions, agencies in the public and private sectors, groups of individuals, etc.) and what role they played in the initiative.

- What were the key challenges in these initiatives?

- What were the key outcomes of these initiatives?

Table 1. Participant Demographics and Professional Titles

\begin{tabular}{ll}
\hline Age & Number of Respondents \\
\hline $30-39$ years & 3 \\
$40-49$ years & 3 \\
$50-59$ years & 3 \\
Over 60 years & 2 \\
Undisclosed & 4 \\
TOTAL & 15 \\
\hline Years of Professional Service & \\
\hline 5 years or less & 1 \\
6-10 years & 7 \\
15-20 years & 1 \\
Over 20 years & 6 \\
TOTAL & 15 \\
\hline Location in Rural SCA County & \\
\hline North Carolina & 3 \\
Tennessee & 8 \\
Virginia & 15 \\
\hline TOTAL & 1 \\
\hline
\end{tabular}

The International Journal of Information, Diversity, \& Inclusion, 3(3), 2019

ISSN 2574-3430, jps.library.utoronto.ca/index.php/ijidi/index

DOI: $10.33137 /$ ijidi.v3i3.32963 


\begin{tabular}{ll}
\hline Self-Identified Professional Title \\
\hline Assistant Director & 1 \\
Branch Supervisor & 1 \\
Business Coordinator/ & 1 \\
HR Specialist & 2 \\
County Director & 1 \\
County Librarian & 1 \\
Director of Libraries & 6 \\
Library Director & 1 \\
Library System Director & 1 \\
Regional Library Director & 15 \\
TOTAL &
\end{tabular}

Participants were also asked to discuss the roles of both the library and the community partners in the initiatives and to identify and discuss related challenges, successes, and key outcomes. The interviews lasted 1-2 hours each and were conducted using a semi-structured format following the framework of the pre-written question guide; however, the procedure also allowed for latitude to pursue additional lines of inquiry or to seek further information from interviewees. Such an approach offered conversational flexibility, opportunity for more substantial responses, and provided for more reliable data (Herman-Kinney \& Verschaeve, 2003; Patton, 1990).

Table 2. Domain Definitions

\begin{tabular}{ll}
\hline Domain Name & Definition \\
\hline Agriculture (D1) & $\begin{array}{l}\text { Initiatives and programming related to and in support of } \\
\text { farming, farmers markets, personal and community } \\
\text { gardening, seed libraries, local food movements, beekeeping, } \\
\text { or other relevant topics of concern. }\end{array}$ \\
Diversity (D2) & $\begin{array}{l}\text { Initiatives and programming related to multicultural issues, } \\
\text { cross-cultural education, immigration, English as a Second } \\
\text { Language, and providing support for minority and } \\
\text { marginalized groups. }\end{array}$ \\
Economy (D3) & Initiatives and programming related to economic issues and \\
& policies, economic development, small business support and \\
\hline
\end{tabular}

The International Journal of Information, Diversity, \& Inclusion, 3(3), 2019

ISSN 2574-3430, jps.library.utoronto.ca/index.php/ijidi/index

DOI: $10.33137 /$ ijidi.v3i3.32963 


\begin{tabular}{ll}
\hline Domain Name & Definition \\
\hline
\end{tabular}

development, job seeking skills, and other similar aspects.

Education (D4)

Initiatives and programming in partnership with and supporting public school systems, private schools, homeschool groups, public and private preschools, and related issues such as literacy, enrichment programs, afterschool programs, summer reading programs, and the like.

Environment (D5)

Initiatives and programming related to issues of environmental health, education, advocacy, protection, and other relevant topics of concern.

Government \& Public Policy (D6)

Initiatives and programming related to matters and questions of social and governmental policies and relevant information needs.

Health (D7)

Initiatives and programming related to issues and support of healthy living, nutrition, well-being, health education, fitness, illness management, mental health, long term care, health insurance, and related matters.

Information Technology (D8)

Initiatives and programming related to or providing education in the realm of various information and communication technologies such as computers, personal devices, Wi-Fi hotspots, and all manner of hardware, software, and associated applications.

Law \& Justice (D9)

Initiatives and programming related to the provision of support, education, advocacy, and resources associated with questions and information needs in the realm of legal matters and concerns.

Manufacturing \& Industry (10) Initiatives and programming in partnership with and supporting manufacturers and various industrial sectors such as those generally related to skills training, workforce development and education, technology training, and others.

Social Welfare (D11)

Initiatives and programming related to and in support of the social well-being of all groups and vulnerable populations such as those that provide meals or shelter, and other provisions or that seek to meet similar needs.

Other (D12)

Initiatives and programming that fall beyond the scope and definitions of all of the above domains.

All participants received and signed an informed consent form approved by the researchers' university Institutional Review Board (IRB) prior to participating in the interview. Each

The International Journal of Information, Diversity, \& Inclusion, 3(3), 2019

ISSN 2574-3430, jps. library.utoronto.ca/index.php/ijidi/index

DOI: $10.33137 /$ ijidi.v3i3.32963 
participant was provided with a $\$ 50$ gift card in appreciation for their contributions and time. For purposes of piloting, feedback was solicited from an advisory team made up of library and community professionals and practitioners regarding the structure and content of the interview questions, which provided useful edits and guidance to the researchers and enhanced the validity of the questions in the interview guide.

\section{Data Analysis}

A grounded theory approach was utilized in the data analysis (Glaser \& Strauss, 1967). The researchers systematically identified categories, themes, and project examples in the participant responses to the interview questions through a process of open, axial, and selective coding (Charmaz, 2014). According to Corbin and Strauss (1990), this type of logical and ordered evaluative process is crucial to an empirical interpretation of such qualitative data.

The data analysis occurred in the following steps. First, transcriptions were made of the audio recordings of the interviews. The interview transcriptions were subsequently compiled into a single digital file and open coding took place as the data was systematically sorted into broad themes. The next step, axial coding, entailed the identification of key topics and themes using illustrative project examples and scenarios of participant responses. Finally, through selective coding, categories, topics, and themes were established that were related to the inquiries of research. The open, axial, and selective coding procedure provided an analytic framework for understanding the data and for an investigation of the thematic relationships found in the responses of the interviewees. Table 3 presents code identifiers, descriptions, and illustrative examples from this research.

Table 3. Codebook

\begin{tabular}{|c|c|c|}
\hline Code Identifier & Description & Examples \\
\hline P1-P15 & $\begin{array}{l}\text { Designates } \\
\text { individual } \\
\text { participants. }\end{array}$ & $\begin{array}{l}\text { P6D7Q2p: "That is a very active health foundation, } \\
\text { and so the library's just a great partner because we } \\
\text { have good parking and a big meeting room and are } \\
\text { always looking for partners." [P6 = Participant } 6 \text {, } \\
\text { Female, Age } 59 \text { years, Regional Director]. }\end{array}$ \\
\hline D1-D12 & $\begin{array}{l}\text { Indicates domain } \\
\text { under which the } \\
\text { response falls. }\end{array}$ & $\begin{array}{l}\text { P11D7Q1p: "We have had blood drives. We've } \\
\text { partnered with the Health Department to come in } \\
\text { and do tables and talk about well-care and taking } \\
\text { care of your children." [D7 = Health]. }\end{array}$ \\
\hline$a, p, c$, or o & $\begin{array}{l}\text { Response type } \\
\text { classification. } \\
\text { a = "aboutness"; } \\
\text { p = partners; } \\
c \text { = challenges; } \\
o \text { = outcomes. }\end{array}$ & $\begin{array}{l}\text { P10D7Q2p: "But, talk about collaboration and } \\
\text { partners. We've got lots of partners with that." } \\
\text { P2D7Q3c: "Our space. Twenty-six hundred square } \\
\text { feet causes some interesting challenges." }\end{array}$ \\
\hline
\end{tabular}

The International Journal of Information, Diversity, \& Inclusion, 3(3), 2019

ISSN 2574-3430, jps.library.utoronto.ca/index.php/ijidi/index

DOI: $10.33137 /$ ijidi.v3i3.32963 


\begin{tabular}{|c|c|c|}
\hline $\begin{array}{l}\text { Q1, Q2, Q3, Q4, } \\
\text { etc. }\end{array}$ & $\begin{array}{l}\text { Question asked in } \\
\text { the interviews. }\end{array}$ & $\begin{array}{l}\text { Q3: What were the key challenges in these } \\
\text { initiatives? Q4: What were the key outcomes of these } \\
\text { initiatives? }\end{array}$ \\
\hline $\mathrm{T} 1, \mathrm{~T} 2$, etc. & $\begin{array}{l}\text { Designates } \\
\text { primary theme or } \\
\text { themes found in } \\
\text { the response. }\end{array}$ & $\begin{array}{l}\text { P9D7Q50: "So, it's a way for people to be in a } \\
\text { private place and do this mental health assessment } \\
\text { without having to go to a clinic or tell anyone that } \\
\text { they think they need help (T6). We haven't seen } \\
\text { that being used very much yet, but we are about to } \\
\text { embark on a big LSTA-funded programming series } \\
\text { with money devoted to mental health (T3) in the } \\
\text { spring and that will be one of the things we try to } \\
\text { advertise and highlight." [T6 = Need for Anonymity; } \\
\text { T3 = Grant Funded Opportunities]. }\end{array}$ \\
\hline $\mathrm{C} 1, \mathrm{C} 2$, etc. & $\begin{array}{l}\text { Designates } \\
\text { category of the } \\
\text { response in } \\
\text { different themes. }\end{array}$ & $\begin{array}{l}\text { P11D7Q5o: “I think we've had a lot more use of the } \\
\text { library as a result of it (T1), which is a great } \\
\text { outcome. Of course, we're hoping that they're } \\
\text { becoming more information literate (T2) about } \\
\text { whatever that topic (T2-C1) is and taking home } \\
\text { more information to improve their family's lives } \\
\text { (T2-C2). All of our programs and activities is about } \\
\text { improving the community (T3)." [T2 = Increased } \\
\text { Information Literacy; T2-C1 = Individual Level; T2-C2 } \\
\text { = Family Level]. }\end{array}$ \\
\hline PE1, PE2, etc. & $\begin{array}{l}\text { Indicates project } \\
\text { examples. }\end{array}$ & $\begin{array}{l}\text { "We have a group that comes and works and meets } \\
\text { with and counsels with victims of domestic violence } \\
\text { (PE2)." [PE2 = Domestic Violence Counseling] }\end{array}$ \\
\hline
\end{tabular}

The researchers first compiled the transcribed responses for each individual participant (P1-P15). Subsequent coding then proceeded by categorizing the content for each question $(\mathrm{Q} 1, \mathrm{Q} 2, \mathrm{Q} 3$, etc.) within the appropriate domain (D1-D12), classifying the response type (aboutness [a], partners [p], challenges [c], outcomes [0]), and, finally, grouping all responses under themes ( $\mathrm{T} 1, \mathrm{~T} 2$, etc.) and related categories ( $\mathrm{C} 1, \mathrm{C} 2$, etc.) in different themes, as relevant, using specific representative responses and project examples (PE1, PE2, etc.). Table 4 provides the response type definitions and examples from the domain of health (D7).

Table 4. Response Type Definitions and Examples from the Domain of Health

\begin{tabular}{|c|c|c|}
\hline Response Type & Definition & Example \\
\hline Aboutness [a] & $\begin{array}{l}\text { Responses that offer } \\
\text { overviews or general } \\
\text { descriptive details about } \\
\text { projects, programs, and }\end{array}$ & $\begin{array}{l}\text { P11D7Q1a: "Last summer, part of our } \\
\text { summer reading was a walking club and } \\
\text { they walked and talked } \\
\text { about the books they'd been reading." }\end{array}$ \\
\hline
\end{tabular}

The International Journal of Information, Diversity, \& Inclusion, 3(3), 2019

ISSN 2574-3430, jps. library.utoronto.ca/index.php/ijidi/index

DOI: $10.33137 /$ ijidi.v3i3.32963 
initiatives.

Partners [p]

Challenges $[\mathrm{c}]$

Outcomes [o]

Responses that name or
specify external
collaborating organizations
and individuals who have
assisted with or
coproduced projects,
programs, or initiatives.

Responses that outline, describe, or reference specific problems, difficulties, obstacles, or complications related to the deployment of projects, programs, and initiatives.

Responses that specify or describe tangible or intangible results, products, or effects of projects, programs, and initiatives.
P6D7Q2p: "They have a very active health foundation and, over the last couple of years, the library there has partnered with the local health foundation to do at least a couple of different program series."

P6D7Q4c: "Well, money's a challenge. Again, we have to do a separate fundraiser, or we couldn't do this just out of our budget. So, we're doing a fundraiser every year to be able to pay for the help and to set up and clean up and provide the programming."

P6D7Q5o: "We do a fundraiser in February to raise enough money to pay a couple of part-time people to kind of run that program just for the summer and it's been really popular and something we're really proud of."

The coding procedure is illustrated in the following examples. The response below from participant (P10) is an example of aboutness [a] in describing initiatives within the past five years in which the library had engaged with external community stakeholders (Q1) related to the domain of health (D7).

P10D7Q1a: "We also have a mental health kiosk (PE1) in the back of the library. All three counties have that and it's kind of like an assessment on a computer that you go through and how are you feeling today or, you know, and it asks a few questions and it's pretty simple and brief. And then, at the end of that assessment, then it will say, ok, what's your zip code and then it will give you resources or like a phone number and there's actually a phone right there."

The researchers identified the mental health kiosk as a project example (PE1) and the theme of stigma associated with mental health issues (T6).

The next example crosses multiple domains and shows a response that related health in relation to other domains. The interview participant (P12) was asked to describe initiatives (Q1) in the domain of environment (D5) and the response illustrates aboutness [a] of a program (PE2) that relates (self-described) to both the health (D7) and the environment (D5) domains as it describes an example that prompts users to engage in an outdoor physical activity (T2) and become environmentally conscious (T1).

The International Journal of Information, Diversity, \& Inclusion, 3(3), 2019

ISSN 2574-3430, jps.library.utoronto.ca/index.php/ijidi/index

DOI: $10.33137 /$ ijidi.v3i3.32963 
P12D5Q1a: "So, what we have are these really cool backpacks (PE2) that are filled with, you know, leaf identification, animal identification, all of those kind of environment identification books (T1) and we have a compass and a magnifying glass, things like that that people can check out and take on a hike with them to improve your health (T2)."

The third example shows a response from a participant (P10) that discusses both partners [p] and outcomes [o] related to initiatives in the domain of health (D7).

P10D7Q2po: “Talk about collaboration and partners. We've got lots of partners with that. The programming (01), we've brought in partners with that and even on a wider basis (T3), like statewide. The American Suicide Prevention Foundation (p1), the NC representative (p2), she's going to come and do some workshops. And the university, Appalachian State University, and their wellness department and Psychology Department, too (p3)."

In this response, the researchers identified the theme of planning and coordination with external stakeholders (T3) with various partners (p1, p2, p3) and one outcome (o1).

In the final example, a participant (P9) responded to a question (Q5) regarding outcomes [o] of initiatives in the domain of health (D7).

P9D7Q5o: "So, it's a way for people to be in a private place and do this mental health assessment (01) without having to go to a clinic or tell anyone that they think they need help (T6). We haven't seen that being used very much yet, but we are about to embark on a big LSTA-funded programming series (02) with money devoted to mental health (T3) in the spring and that will be one of the things we try to advertise and highlight."

The researchers identified in this response the themes of (T3) budget issues and (T6) stigma associated with mental health problems as well as two outcomes, one for the library (02) and one for the users (01).

\section{Findings}

The following sections highlight key research findings related to the "aboutness", partners, challenges, and outcomes rural librarians reported of their health-based initiatives in community engagement.

\section{"Aboutness" of Health-Based Community Engaged Initiatives}

From summer feeding programs to healthy living reading activities (e.g., on mental health and drug abuse), dental screening workshops, walking and exercise clubs, health materials for specific population subgroups (e.g., teens, elderly, Spanish speakers, etc.), healthy food vending machines and health programming series, domestic violence counseling, health fairs and free clinics, health insurance informational sessions, and mental health kiosks, the examples are many of rural library engagement with community stakeholders. Figure 1 visualizes select examples of specific health-related responses, programs, services, and other information offerings rural librarians participating in this research shared in this study.

The International Journal of Information, Diversity, \& Inclusion, 3(3), 2019

ISSN 2574-3430, jps. library.utoronto.ca/index.php/ijidi/index

DOI: $10.33137 /$ ijidi.v3i3.32963 


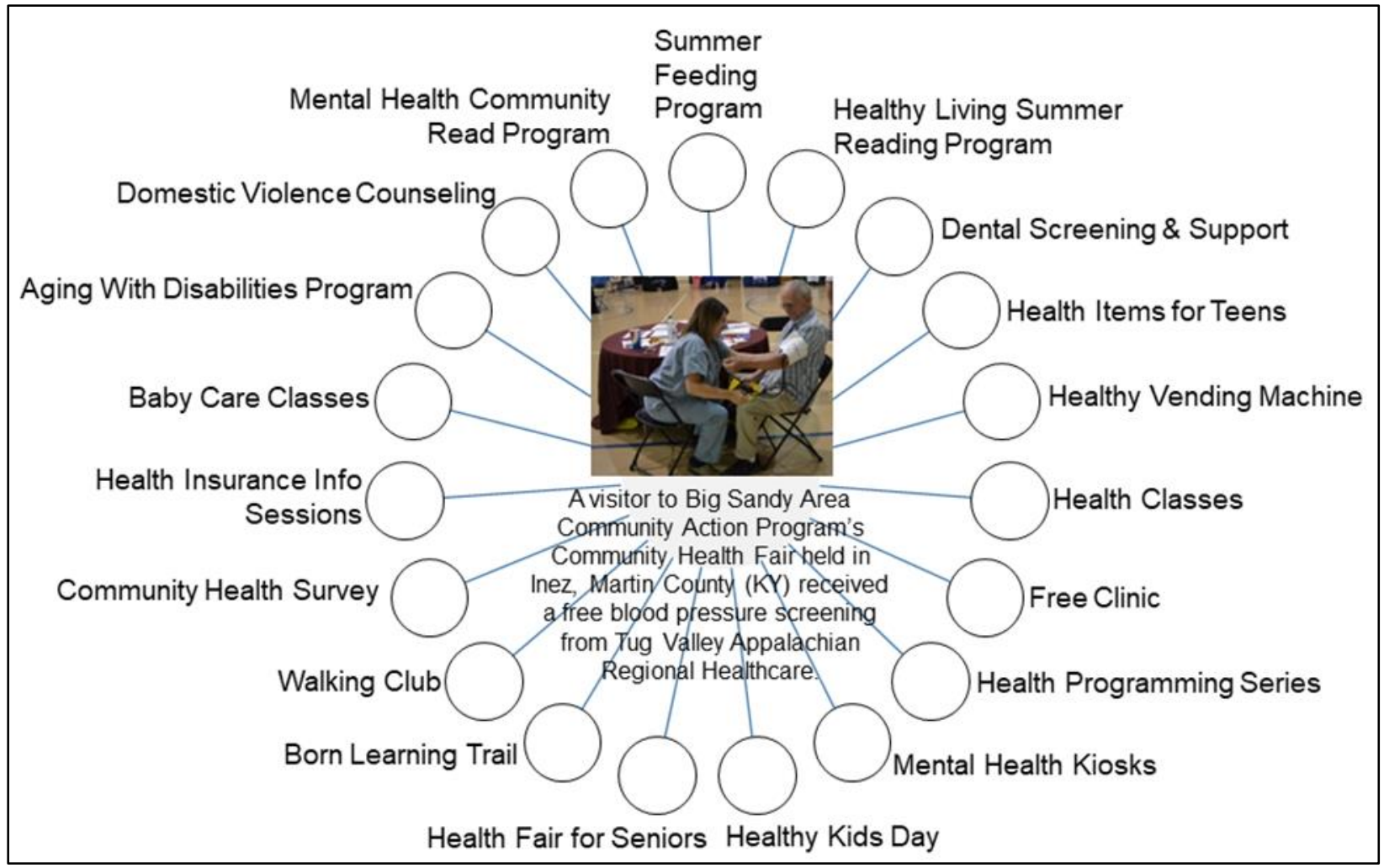

Figure 1. Health-related information offerings of rural libraries engaging their communities.

Rural librarians discussed their health-related information offerings in terms of community engagement in individual-centered activities such as one-on-one appointments for explanation of Affordable Care Act and community information referrals for health insurance, amongst others. They also described their engaged information responses in terms of programming and events for specific collective groups (e.g., seniors, kids) or open-to-public happenings such as Tai Chi classes, yoga classes, Breast Cancer lunch ' $n$ ' learn, diabetes management classes, healthy cooking classes for children, etc. The following health-related scenario illustrates a rural library community-engaged example:

"Part of what I do is work with a free sustained clinic to provide education for chronic disease management and to partner to reach more clientele, the working uninsured, for people that sort of fall between the cracks, you know, they're working but they either are not provided insurance through their place of employment or else they're underinsured if they have insurance...Or with some people who were able to get insurance, but still they couldn't afford the premium under the Affordable Care Act. So, we partner with people that are in our community and provide health services like doctors, nurses, that serve as library board members, and we work with them through grants and contracts and local fundraising, to support the clinic and to provide healthcare not just for our one county, but for about a three-county area."

The International Journal of Information, Diversity, \& Inclusion, 3(3), 2019

ISSN 2574-3430, jps.library.utoronto.ca/index.php/ijidi/index

DOI: $10.33137 /$ ijidi.v3i3.32963 


\section{Collaborating Partners in Health-Based Community-Engaged Initiatives}

Participants shared a range of collaborators in their health-based community-engaged initiatives. Figure 2 selectively visualizes a taxonomic classification of partner types with specific examples.

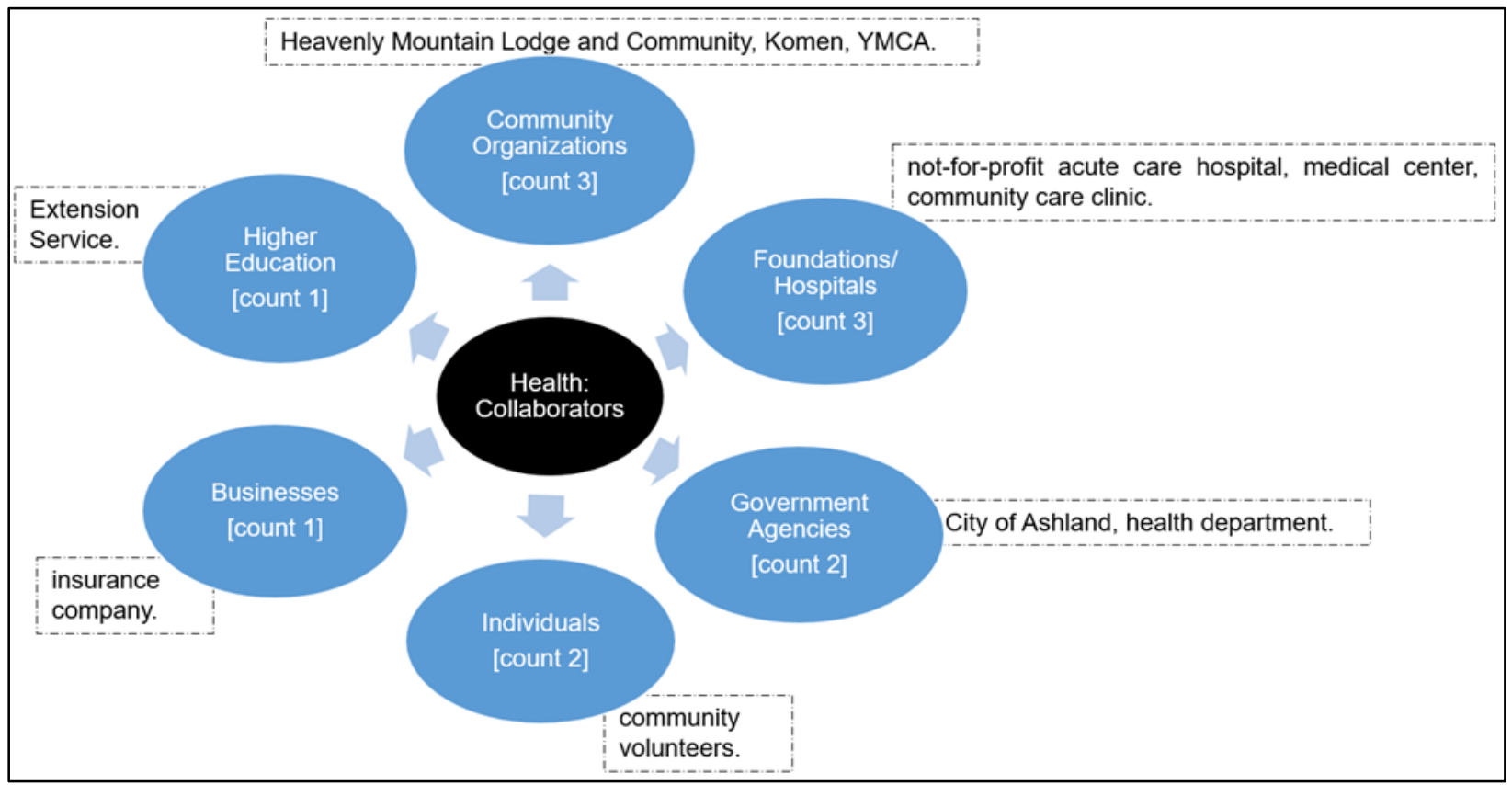

Figure 2. Selective taxonomic classification of health-based partner types in rural library community engaged initiatives with specific examples.

The following two scenarios identify collaborators and partnerships in health-based communityengaged initiatives highlighting the "out-of-the-box" efforts that are getting operationalized and implemented in rural library settings:

Service: Health Programming Series

"In Wilkes County, they have a very active health foundation and, over the last couple of years, the library there has partnered with the local health foundation to do at least a couple of different programs...The Susan B. Komen breast cancer program has been presented in each of my libraries in each of my counties. And again, that's just something they offer that we're happy to offer a home for."

Service: Health Classes

"We partner with the Extension Office...You really have to rely on your partners because library staff can give you book information about it, but we're not trained health professionals, so we certainly don't want to speak to health things that we don't know about."

The International Journal of Information, Diversity, \& Inclusion, 3(3), 2019

ISSN 2574-3430, jps.library.utoronto.ca/index.php/ijidi/index

DOI: $10.33137 /$ ijidi.v3i3.32963 


\section{Challenges in Community-Engaged Rural Health}

Participants reported challenges reflected in their health-related experiences that were intertwining owing to the impact of limited availability of resources, time, space, and staff working under constraining conditions. For example, shortage of financial resources had a "ripple effect" in having limited monies to build additional space (or rent larger premises) and few salaried staff whose time was at a premium, utilized only for certain amount of prioritized work possible within the available time. The three prioritized themes related to challenges in health rural library community engagement efforts included: Community characteristics (e.g., lack of public awareness) in rural settings, limited resource availability, and resource management and organization in the context of constraining circumstances (e.g., meager staff training, poor technological infrastructures, etc.). These were seen as major hurdles to address and overcome in the development of community-engaged health activities by rural libraries. Table 5 illustrates these themes and select categories of challenges in the domain of health.

The following scenarios illustrate these important concerns:

Lack of Public Awareness

"I would say that meeting and attracting your target population is probably our biggest challenge. Information sharing about our programs. Making sure it's in the paper and on Facebook...You have to really be mindful when you're planning for your resources or your health programs that people may be limited as far as being able to take advantage of that. They may not have that background. They might not be library-oriented...maybe, you know, growing up they didn't avail themselves to library services. So, it's not an automatic mindset for them to think that the library may have the answer or the library may have the health resources. So, it's really educating people as well as providing the services."

Limited Resources and Space

"If you could imagine three hundred and fifty people in twenty-six hundred square feet...In April, I'm going to do a session on the logistics of programming from fifty to three and fifty in twenty-six hundred square feet and some of the lessons we have learned on furniture purchasing, staff management, computer purchasing, chairs, and how we have come to deal with that issue."

Limited Planning, Organizing, and Managing Resources

"For the summer feeding program, with schools, it was a little bit chaotic, the planning...I can't recruit volunteers if I don't know the details on your end...somewhere the paperwork didn't get filed, it was not as organized as I would prefer...we learned that kids don't care about sandwiches, they want a hot lunch and, the library does not have the equipment to keep it hot...as I said, this community self-segregates. And, all of my volunteers were Caucasian and occasionally some African-American kids would look into the room where we had the lunches and look around and then leave. I don't know what was motivating that, but, you know, it's unfortunate."

The International Journal of Information, Diversity, \& Inclusion, 3(3), 2019

ISSN 2574-3430, jps.library.utoronto.ca/index.php/ijidi/index

DOI: $10.33137 /$ ijidi.v3i3.32963 
Table 5. Select Illustrative Theme and Category Descriptions Related to Challenges in the Domain of Health

\begin{tabular}{|c|c|c|c|c|}
\hline Code & $\begin{array}{l}\text { Theme } \\
\text { Identifier }\end{array}$ & $\begin{array}{l}\text { Theme } \\
\text { Description }\end{array}$ & $\begin{array}{l}\text { Category } \\
\text { Identifier }\end{array}$ & $\begin{array}{l}\text { Category } \\
\text { Description }\end{array}$ \\
\hline P9D7Q4C & $\mathrm{T} 1$ & $\begin{array}{l}\text { Lack of Public } \\
\text { Awareness }\end{array}$ & $\mathrm{C} 2 ; \mathrm{C} 3 ; \mathrm{C7}$ & $\begin{array}{l}\text { C7 = Target } \\
\text { Population; C2 = } \\
\text { Use of Social Media; } \\
\text { C3 = Public } \\
\text { Education About } \\
\text { Library Resources. }\end{array}$ \\
\hline P2D7Q4C & $\mathrm{T} 2$ & $\begin{array}{l}\text { Limited } \\
\text { Resources and } \\
\text { Space }\end{array}$ & $\mathrm{C} 1$ & $\begin{array}{l}\text { C1 = Programming } \\
\text { Logistics. }\end{array}$ \\
\hline P1D7Q4C & $\mathrm{T} 3$ & $\begin{array}{l}\text { Limited } \\
\text { Planning, } \\
\text { Organizing, and } \\
\text { Managing } \\
\text { Resources }\end{array}$ & C4; C5 & $\begin{array}{l}\text { C4 = Volunteers; C5 } \\
=\text { Lack of Resources. }\end{array}$ \\
\hline P9D7Q4C & $\mathrm{T} 4$ & $\begin{array}{l}\text { Need for } \\
\text { Organized Efforts } \\
\text { in Program } \\
\text { Assessment, } \\
\text { Evaluation, and } \\
\text { Documentation }\end{array}$ & $\mathrm{C} 6$ & $\begin{array}{l}\mathrm{C} 6 \text { = Measurement } \\
\text { of Impacts and } \\
\text { Outcomes. }\end{array}$ \\
\hline
\end{tabular}

Need for Organized Efforts in Program Assessment, Evaluation, and Documentation

"We are really, really bad at measuring impacts and outcomes. We're...kind of one of our organizational goals for the next year is to try to start tracking outcomes using PLA's projects outcomes. So, right now, it's all anecdotal, but we hope to do a little bit better in the future."

\section{Outcomes in Health-Based Community-Engaged Initiatives}

Select scenarios in the following specific project examples spotlight health-based outcomes in rural library community engagement:

Project 1: Healthy Living/Summer Reading Program

"That began about four years ago that we have had the medical practitioner out regularly to assist us and us to assist her in getting our families the best information that they can have on healthy eating and healthy living... I think one of our programs that we did happened every Thursday morning during summer reading for children, and it's actually making sure that the people that especially need the information

The International Journal of Information, Diversity, \& Inclusion, 3(3), 2019

ISSN 2574-3430, jps.library.utoronto.ca/index.php/ijidi/index

DOI: $10.33137 /$ ijidi.v3i3.32963 
get it. Often, it's the ones that are interested are already doing a lot of those practices."

Project 2: Dental Screenings and Support

"We also partner with the Department of Health and do dental screenings, because there is equipment to set up that they do not like to take down every day, we advertise all through summer, in the newspaper and on Facebook, and every year our numbers have increased. We kind of doubled our numbers this last summer over the previous summer."

Project 3: Health Materials for Teens/Seniors

"We collected hygiene items for teens, partnered with the Family Resource Center, basically do a bag for them for Christmas, like a stocking, for teens who don't have, like, shampoo or soap or a comb or wash cloths... asked for donations so that we can give to them before they go home over winter break. So, we collect items here. We ask patrons to bring them in and, if they do, we waive their fines.... we also do a collection for the elderly where we collect hygiene items as well."

Project 4: Healthy Vending Machines

We have a healthy vending machine that we put here for a healthy snack option for children and patrons. They can basically purchase ... I think it has, like, juices and stuff in it and, like, granola bars and nuts.

Project 5: Health Literacy

"We partner with the health and medical providers to help our community becoming more information literate about whatever that topic is and taking home more information to improve their family's lives. All of our programs and activities is about improving the community either individually or as a family as a whole. And, I'm sure that we've gotten more library use out of opening up our library and having these programs in and people seeing what's available for them here."

Project 6: Domestic Violence Counseling

"We have a group that comes and works and meets with and counsels with victims of domestic violence in quiet, out-of-the-way space where people don't see them coming and going...So, it's a way for people to be in a private place and do this mental health assessment without having to go to a clinic or tell anyone that they think they need help...we are about to embark on a big LSTA-funded programming series on mental health in the spring and that will be one of the things we try to advertise and highlight."

Project 7: Mental Health Community Read Program

"The American Suicide Prevention Foundation, the NC representative, she's done some workshops. And the university, Appalachian State University, and their wellness department and Psychology Department, too... So, also, a lot of suicide prevention

The International Journal of Information, Diversity, \& Inclusion, 3(3), 2019

ISSN 2574-3430, jps.library.utoronto.ca/index.php/ijidi/index

DOI: $10.33137 /$ ijidi.v3i3.32963 
awareness is going on and, with the workshops, that foundation does Toxic Lives and they do it with different age groups and providers, seniors. So, they're going to be doing a couple of those programs at the local senior centers, but also one at the library."

Project 8: Healthy Kids Day

"It's everything from health, nutrition, animals, sports, and things like that. And, we usually have about four hundred to five hundred people come through in four hours' time. So, it's a big, huge event...the kids are excited. They make their parents post it on the refrigerator, circle the calendar. They know how much fun they're going to have because everything is free. There's no cost at anything."

Project 9: Health Fair for Seniors

"The seniors get the blood pressure. They find out what all is available to them if they've just moved here in the county. They can find out from the librarian what's available to them that they didn't know at the different agencies...she's handing out insurance forms, she will even do classes at the nursing home or here or at the senior center about how to do your finances for later on...insurance needs and things like that."

Project 10: Born Learning Trail with Health Kiosks

"And so, we got grants to do a Born Learning trail and then we got grants to do learning kiosks...Part of our money came from the United Way through the Healthy Community Action Team...the catch phrase I was using was creating healthy kids from head to toe...so, the idea that we would work together to help kids get more activity. And so, their goal was [to] fight childhood obesity."

Project 11: Walking Club

"Last summer, part of our summer reading was a walking club and they walked and talked about the books they'd been reading while exercising."

Project 12: Aging with Disabilities Program

"We have had groups from the hospital that came and met about children with disabilities. Just families talking to the librarian and nurses about how to cope with and how to deal with if they're aging and they're trying to plan for what's going to happen to their child who can't be alone in the world when they're gone."

\section{Discussion}

Rural librarians provided a diverse range of descriptions of their health-related communityengaged initiatives. Readers can recognize from the scenarios represented in this article that a common meta-level theme that also emerged from our analysis of participant feedback is related to a cross-over of health with other domains. Several examples were discussed; the following is a scenario of an interviewee that represents cross-over of health programming with need to generate education impacts in the Teen Day Program Germ City:

The International Journal of Information, Diversity, \& Inclusion, 3(3), 2019

ISSN 2574-3430, jps. library.utoronto.ca/index.php/ijidi/index

DOI: $10.33137 /$ ijidi.v3i3.32963 
"...we participated in Tullahoma city during the summer break in special programs for kids...partnered with the Department of Health in the Germ City, actually, a small tent, probably about at least seven feet tall, we set that up so children could see how...whether or not they were doing a good job at hand-washing...we had simulated, there is, like, a lotion or powder that children put on their hands and then they go wash their hands and then they come back and then where they didn't get their hands clean, it glowed in the dark. So, they would then get some information about cleaning habits and importance to their health."

Another participant shared cross-over of health with the environment and education as illustrated in the following scenario about "green cleaning":

"We have a program on green cleaning in helping people to just think about how hazardous some of the over-the-counter cleaning products are and helping people to economically make some of their own home cleaner."

These instances illustrate that in the development of health information-related offerings, an important strategy rural librarians adopted in their conceptualization, operationalization, and implementation of the health-related initiatives was a consideration of generating outcomes in various spheres of people's lives, such as agriculture, diversity, economics, education, environment, information technology use, law, manufacturing skills, social welfare, and others. Their community-engaged activities in health efforts were always considered in relation to how delivery of their information-related offerings would impact other aspects of people's lives. Figure 3 shows these intertwining aspects of health with other domains of activities in people's lives.

Figure 3 also identifies the importance of considering the return-on-investment and/or economic impact in rural librarians' planning and implementing of health-related initiatives. This theme was reflected across all participants' feedback in their intentional consideration of evaluating the health information offerings through the lens of return-on-investment (i.e., cost-benefit analysis) and/or potential economic impacts prior to their implementation. Reflecting on this value of the health-information offerings from a library-centric perspective provided thoughtful appraisal of what resources the rural library was investing in to generate what kinds of potential benefits. Rural librarians were also reviewing user-centered points of view of their possible economic returns while deciding to make avail of the health initiatives provided at the library.

These valuations and the assessment of the impact of health-related initiatives on multiple domains makes logical sense especially in the light of constraining resource availability and other extenuating circumstances librarians and their patron communities encountered in their rural environments. Generating positive impacts across different domains/spheres of activity in people's lives provided a strong justification for enacting such activities as well as requesting funding resources to support the delivery of such information-related offerings.

The International Journal of Information, Diversity, \& Inclusion, 3(3), 2019

ISSN 2574-3430, jps. library.utoronto.ca/index.php/ijidi/index

DOI: $10.33137 /$ ijidi.v3i3.32963 


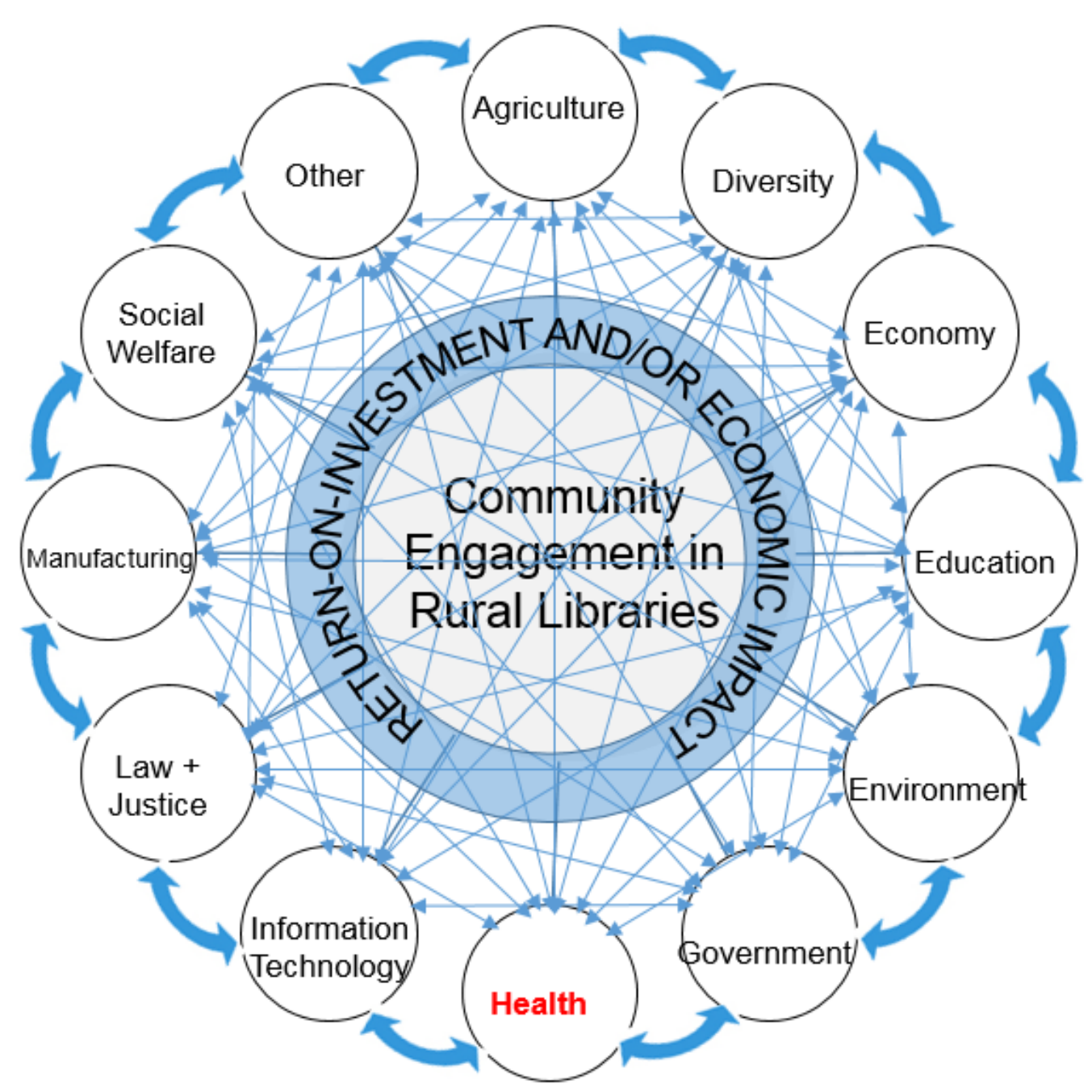

Figure 3. Intertwining Aspects of Health with Other Domains of Activities in People's Lives.

\section{Conclusion}

Select scenarios presented in this article provide a glimpse of community-engaged health-related practices and experiences of rural librarians in the SCA region. As tools to further health justice within the broader context of marginalization in the LIS professions, they provide a "voice" of / to rural librarians towards individual, social, and community empowerment. These narratives also serve to highlight the understanding of health-related information offerings in the context of their impacts on other domains representing the intertwining elements in the lives of rural residents. As a result, they provide strong justification for the rural librarians to plan and implement health initiatives in terms of constructs related to return-on-investment associated with impacts generated across multiple settings. Realistically, such an approach provides

The International Journal of Information, Diversity, \& Inclusion, 3(3), 2019

ISSN 2574-3430, jps.library.utoronto.ca/index.php/ijidi/index

DOI: $10.33137 /$ ijidi.v3i3.32963 
potential opportunities to rural librarians to include community partnerships across different spheres to facilitate successful delivery of health-related information services. For example, in the planning of a book talk on holistic health, rural librarians can also map impacts on agriculture in terms of improvements in organic food production, on education in helping children and teens learn of nutrition and eating habits, on environment in terms of facilitating sustainable farming, on diversity in anchoring the conversations to needs of specific populations (such as seniors, lowincome families, racial/ethnic groups, etc.), and so on. Health and medical service providers, local non-profit farmers, K-12 teachers and students, environmentalists, and others might be interested in the planning and management of such an event since it would relate to their vested interest. In this manner, the rural librarian can garner community support of individuals, groups, organizations, institutions, and others to come together in the provision of support, staff, money, resources, time, etc. that might lead to a more effective delivery and success of such initiatives.

Theoretically, this research highlighted the need for expanding the human information behavior discourse (in health information and the broader information context) and library services/practices design work to understand the information creation-organizationmanagement-dissemination processes beyond theory and practice in its inclusion of impact and outcome-driven constructs (Mehra, Sikes, \& Singh, 2018). Methodologically, strategies and approaches of inclusion of rural libraries and community engagement in health information research are also new directions to pursue in future studies.

\section{Acknowledgements}

The authors appreciate the IMLS planning grant reported in this article. We also thank the grant partners and research respondents for their valuable support and involvement. Thanks to Chris Barrett for loaning his skills of visualization.

\section{Endnotes}

1 The term "rural" used in this article encompasses several meanings and characteristics. These include the U. S. Census Bureau's definition as areas with fewer than 2,500 people and open territory (Economic Research Service, 2007). It also recognizes The Encyclopedia of Rural America's related concept of "nonmetropolitan" counties to include the spread of housing developments outside the boundaries of metro areas that have no cities with as many as 50,000 residents (Rathge, 1997), in addition to being non-urbanized (OMB, 1998). Further, the meaning of rural areas according to the U. S. Census Bureau (2010) is also significant in terms of anything not deemed an Urban Area (which is defined as having a population density of at least 1,000 people per square mile and surrounding census blocks with an overall density of at least 500 people per square mile).

2 See grant website for details at URL: http://scholar.cci.utk.edu/ca2ca-sca-rl.

3 The Appalachian Regional Commission (ARC), created as a Unites States federal-state partnership, demarcates Appalachia to include 420 counties in Alabama, Georgia, Kentucky, Maryland, Mississippi, New York, North Carolina, Ohio, Pennsylvania, South Carolina, Tennessee, Virginia, and West Virginia. The ARC (1974) identifies Central Appalachia to include: West Virginia's nine southernmost counties, eastern Kentucky, Virginia's southwestern

The International Journal of Information, Diversity, \& Inclusion, 3(3), 2019

ISSN 2574-3430, jps.library.utoronto.ca/index.php/ijidi/index

DOI: $10.33137 /$ ijidi.v3i3.32963 
tip, and the northwestern portion of Tennessee's Appalachian area (Bush, 2003), while southern Appalachia includes: most of Appalachian Virginia and Tennessee as well as the western Carolinas and the northern parts of Georgia, Alabama, and Mississippi.

\section{References}

Andrews, T., Dyson, L., \& Wishart, J. (2015). Advancing ethics frameworks and scenario-based learning to support educational research into mobile learning. International Journal of Research \& Method in Education, 38(3), 320-334. http://dx.doi.org/10.1080/1743727X.2015.1026252

Appalachian Regional Commission (ARC). (n.d.a). The Appalachian region. Washington, DC: Appalachian Regional Commission. Retrieved from https://www.arc.gov/appalachian_region/TheAppalachianRegion.asp

Appalachian Regional Commission (ARC). (n.d.b). Appalachian Regional Commission (Homepage). Washington, DC: Appalachian Regional Commission. Retrieved from https://www.arc.gov/index.asp

Appalachian Regional Commission (ARC). (1974). The new Appalachian subregions and their development strategies. Appalachia, a Journal of the ARC, 8, 11-27.

Appalachian Regional Commission (ARC). (February 2015a). Appalachia then and now: Examining changes to the Appalachian region since 1965. Washington, DC: Appalachian Regional Commission. Retrieved from https://www.arc.gov/assets/research_reports/AppalachiaThenAndNowCompiledReport $\underline{\text { s.pdf }}$

Appalachian Regional Commission (ARC). (2015b). Investing in Appalachia's future: The Appalachian Regional Commission's five-year strategic Plan for Capitalizing on Appalachia's Opportunities, 2016-2020. Washington, DC: Appalachian Regional Commission. Retrieved November 24, 2018, from https://www.arc.gov/images/newsroom/publications/sp/InvestinginAppalachiasFuture ARCs2016-2020StrategicPlan.pdf

Appalachian Regional Commission (ARC). (2017a). County economic status in Appalachia, FY 2018. Washington, DC: Appalachian Regional Commission. Retrieved from https: / / www.arc.gov/research/mapsofappalachia.asp?MAP_ID=137

Appalachian Regional Commission (ARC). (2017b). Performance and accountability report: fiscal year 2016. Washington, DC: Appalachian Regional Commission. Retrieved from https://www.arc.gov/images/newsroom/publications/fy2016par/FY2016Performancea ndAccountabilityReport.pdf

Baker, L., Spang, L., \& Gogolowski, C. (1998). The provision of consumer health information by Michigan public librarians. Public Libraries, 37(4), 250-255.

Barr-Walker, J. (2016). Health literacy and libraries: A literature review. Reference Services

The International Journal of Information, Diversity, \& Inclusion, 3(3), 2019

ISSN 2574-3430, jps.library.utoronto.ca/index.php/ijidi/index

DOI: $10.33137 /$ ijidi.v3i3.32963 
Review, 44(2), 191-205. https://doi.org/10.1108/RSR-02-2016-0005

Behringer, B., Friedell, G. H., Dorgan, K. A., Hutson, S. P., Nancy, C., Phillips, A., Krishnan, K., \& Cantrell, E. S. (2007). Understanding the challenges of reducing cancer in Appalachia: Addressing a place-based health disparity population. Californian Journal of Health Promotion (Special Issue: Health Disparities \& Social Justice), 5, 40-49.

Belenky, M. F., Clinchy, B. M., Goldberger, N. R., \& Tarule, J. M. (1986). Women's ways of knowing: The development of self, voice, and mind. New York, NY: Basic Books.

Borman, C., \& McKenzie, P. (2005). Trying to help without getting in their faces: Public library staff descriptions of providing consumer health information. Reference \& User Services Quarterly, 45(2), 133-146.

Bush, W. S. (2003). Bridging the gap between culture and mathematics: The Appalachian perspective. Athens, GA: Appalachian Collaborative Center for Learning, Assessment, and Instruction in Mathematics, Ohio State University.

Campbell, J. (2016). Beyond the silence: Women's unheard voices from the troubles. London, UK: Guildhall Press.

Carroll, J. M. (1995). Introduction: The Scenario Perspective on System Development. In J. Carroll (ed.), Scenario-based design: Envisioning work and technology in system development (pp. 1-17). New York, NY: John Wiley \& Sons.

Carroll, J. M. (2003). Making use: Scenario-based design of human-computer interactions ( $1^{\text {st }}$ edition). Cambridge, MA: The Massachusetts Institute of Technology.

Catte, E. (2018). What you are getting wrong about Appalachia (1 $1^{\text {st }}$ edition). Cleveland, OH: Belt Publishing.

Charmaz, K. (2014). Constructing grounded theory (2nd ed.). Thousand Oaks, CA: Sage.

Charmaz, K. (2006). Constructing grounded theory: A practical guide through qualitative analysis. London, UK: Sage Publications.

Chobot, M. (2004). The challenge of providing consumer health information services in public libraries. Washington, DC: American Association for the Advancement of Science.

Corbin, J., \& Strauss, M. (1990). Grounded theory research: Procedures, canons, and evaluative criteria. Qualitative Sociology, 13(1), 3-21.

Dey, I. (1999). Grounding grounded theory. San Francisco, CA: Academic Press.

Economic Development Research Group. (2007). Sources of regional growth in non-Metro Appalachia. Cambridge, MA: Department of Urban Studies and Planning, Massachusetts Institute of Technology. Retrieved from https: / / www.arc.gov/research/researchreportdetails.asp?REPORT_ID=84

Eller, R. (2008). Uneven ground: Appalachia since 1945. Lexington, KY: University Press of

The International Journal of Information, Diversity, \& Inclusion, 3(3), 2019

ISSN 2574-3430, jps. library.utoronto.ca/index.php/ijidi/index

DOI: $10.33137 /$ ijidi.v3i3.32963 
Kentucky.

Eng, T., Maxfield, A., Patrick, K., Deering, M., Ratzan, S., \& Gustafson, D. (1998). Access to health information and support: A public highway or a private road? JAMA, 280(15), 1371-1375.

Eysenbach, G., \& Kohler, C. (2002). How do consumers search for and appraise health information on the World Wide Web? Qualitative study using focus groups, usability tests, and in-depth interviews. British Medical Journal, 324(7337), 573-577.

Federal Communications Commission. (2012). Bringing broadband to rural America: Report on a rural broadband strategy. Scotts Valley, CA: CreateSpace Independent Publishing Platform.

Flaherty, M. G. (2018). Promoting individual and community health at the library. Chicago, IL: American Library Association.

Flaherty, M. G. (2016). From Google to MedlinePlus: The wide range of authoritative health information provision in public libraries. Library and Information Science Research, 38(2), 101-107. https: //doi.org/10.1016/j.lisr.2016.04.001

Flaherty, M. G. (2013). Consumer health information provision in rural public libraries: A comparison of two library systems. The Library Quarterly: Information, Community, Policy, 83(2), 155-165. https://doi.org/10.1086/669548

Flaherty, M. G., \& Grier, P. (2014). Statewide initiative to embed consumer health librarians in public libraries: A case study. Public Library Quarterly, 33(4), 296-303.

https://doi.org/10.1080/01616846.2014.970109

Flaherty, M. G., \& Kaplan, S. (2016). Health information: Print materials assessment in public libraries. Reference Services Review, 44(2), 163-177. https://doi.org/10.1108/RSR-02$\underline{2016-0010}$

Flaherty, M. G., \& Miller, D. (2016). Rural public libraries as community change agents: Opportunities for health promotion. Journal of Education for Library and Information Science, 57(2), 143-150. https://doi.org/10.3138/jelis.57.2.143

Gillaspy, M. (2005). Factors affecting the provision of consumer health information in public libraries: The last five years. Library Trends, 53(3), 480-495.

Glaser, B., \& Strauss, A. (1967). The discovery of grounded theory: Strategies for qualitative research (observations). Chicago, IL: Aldine.

Gutschall, M., Thompson, K., \& Lawrence, E. (2018). Addressing health disparities in rural nutrition practice: A qualitative model from rural Appalachia. Journal of Hunger \& Environmental Nutrition, 13(1), 84-99. https: / / doi.org/10.1080/19320248.2017.1337536

Hamby, S. (2018). Resisting technology, Appalachian style. Scientific American, April 4, 2018. Retrieved January 23, 2019, from

The International Journal of Information, Diversity, \& Inclusion, 3(3), 2019

ISSN 2574-3430, jps.library.utoronto.ca/index.php/ijidi/index

DOI: $10.33137 /$ ijidi.v3i3.32963 
https://www.scientificamerican.com/article/resisting-technology-appalachian-style/

Harris, R., Henwood, F., Marshall, A., \& Burdett, S. (2010). "I'm not sure if that's what their job is": Consumer health information and emerging "healthwork" roles in the public library. Reference and User Services Quarterly, 49(3), 239-252. http: //dx.doi.org/10.2307/20865260

Helsper, E. (2010). Gendered Internet use across generations and life stages. Communication Research, 37(3), 352-374.

Herman-Kinney, N., \& Verschaeve, J. (2003). Methods of symbolic interactionism. In Reynolds, L. \& Herman-Kinney, N. (eds.), Handbook of symbolic interactionism (pp. 213-252). Walnut Creek, CA: AltaMira Press.

Horrigan, J.B. (2015). Libraries at the crossroads. Washington, DC: Pew Internet \& American Life Project. Retrieved November 25, 2018, from http://www.pewinternet.org/2015/09/15/libraries-at-the-crossroads/

Jaeger, P., Wentz, B., \& Bertot, J. (2015). Libraries and the future of equal access for people with disabilities: Legal frameworks, human rights, and social justice. In B. Wentz, P. T. Jaeger, J. C. Bertot (eds.) Accessibility for persons with disabilities and the inclusive future of libraries (Advances in Librarianship, 40) (pp. 237-253). London, UK: Emerald Publishing.

Kruger, T. M., Swanson, M., Davis, R. E., Wright, S., Dollarhide, K., \& Schoenberg, N. E. (2012). Formative research conducted in rural Appalachia to inform a community physical activity intervention. American Journal of Health Promotion, 26(3), 143-151. https://doi.org/10.4278/ajhp.091223-QUAL-399

Kwon, N., \& Kim, K. (2009). Who goes to a library for cancer information in the e-health era? A secondary data analysis of the Health Information National Trends Survey (HINTS). Library and Information Science Research, 31(3), 192-200. https://doi.org/10.1016/j.lisr.2009.01.006

Lukenbill, B., \& Immroth, B. (2009). School and public youth librarians as health information gatekeepers: Research from the lower Rio Grande Valley of Texas. School Library Media Research: Research Journal of the American Association of School Librarians, 12, 1-30.

http://www.ala.org/aasl/sites/ala.org.aasl/files/content/aaslpubsandjournals/slr/vol 12/SLMR_SchoolPublicLibrarians_V12.pdf

Malachowski, M. (2014). Public libraries participating in community health initiatives. Journal of Hospital Librarianship, 14(3), 295-302. https://doi.org/10.1080/15323269.2014.924754

Mehra, B. (2014). Perspectives of rural librarians about the information behaviors of children with special needs in the Southern and Central Appalachian Region: An exploratory study to develop user-centered services. In D. Bilal \& J. Beheshti (Eds.), New directions in children and adolescents' information behavior research (pp. 157-189). Cambridge, MA: Emerald. 
Mehra, B. (2015). Introduction. Library Trends: Social Justice in Library and Information Science \& Services, 64(2), 179-197. https://doi.org/10.1353/lib.2015.0042

Mehra, B. (2017). Mobilization of rural libraries towards political and economic change in the aftermath of the 2016 presidential election. The Library Quarterly: Information, Community, Policy, 87(4), 369-390. https://doi.org/10.1086/692303

Mehra, B., Albright, K., \& Rioux, K. (2006). A practical framework for social justice research in the information professions. Proceedings of the American Society for Information Science and Technology, 43(1), 1-10. https://doi.org/10.1002/meet.14504301275

Mehra, B., Bishop, A. P., Bazzell, I., \& Smith, C. (2002). Scenarios in the Afya Project as a participatory action research (par) tool for studying information seeking and use across the "Digital Divide." Journal of the American Society of Information Science and Technology, 53(14), 1259-1266.

Mehra, B., Bishop, B. W., \& Partee II, R. P. (2016). Information science professionals as community action researchers to further the role of rural public libraries in small business economic development: A case study of Tennessee. Canadian Journal of Information and Library Science, 40(4), 289-299.

Mehra, B., Bishop, B. W., \& Partee II, R. P. (2017a). How do public libraries assist small businesses in rural communities? An exploratory qualitative study in Tennessee. Libri: International Journal of Libraries and Information Studies, 67(4), 245-260. https://doi.org/10.1515/libri-2017-0042

Mehra, B., Bishop, B. W., \& Partee II, R. P. (2017b). Small business perspectives on the role of rural libraries in economic development. The Library Quarterly: Information, Community, Policy, 87(1), 17-35. https://doi.org/10.1086/689312

Mehra, B., Bishop, B. W., \& Partee II, R. P. (November 2017c). A gap analysis of the perspectives of small businesses and rural librarians in Tennessee: Implications towards a blueprint design of a public library small business toolkit. In B. Real (Ed.), Rural and small public libraries: Challenges and opportunities (Advances in Librarianship, 43) (pp.97-121). Bingley, UK: Emerald Group Publishing. https://doi.org/10.1108/S0065$\underline{283020170000043005}$

Mehra, B., Bishop, B. W., \& Partee II, R. P. (2018). A case methodology of action research to promote economic development: Implications for LIS education. Journal of Education for Library and Information Science, 59(1-2), 48-65. https://doi.org/10.3138/jelis.59.1-2.06

Mehra, B., Black, K., Singh, V., \& Nolt, J. (2011). What is the value of LIS education? A qualitative analysis of the perspectives of rural librarians in Southern and Central Appalachia. Journal of Education for Library and Information Science, 52(4), Fall 2011, 265-278.

Mehra, B., \& Rioux, K. (Eds.). (2016). Progressive community action: Critical theory and social justice in library and information science. Sacramento, CA: Library Juice Press.

The International Journal of Information, Diversity, \& Inclusion, 3(3), 2019

ISSN 2574-3430, jps.library.utoronto.ca/index.php/ijidi/index

DOI: $10.33137 /$ ijidi.v3i3.32963 
Mehra, B., Sikes, E. S., \& Singh, V. (2018, November). Information technology use behaviors of community-engaged rural librarians: A future beyond the theory-practice discourse to integrate impact, 2018 ASIS\&T SIG-USE Symposium: Moving toward the future of information behavior research and practice, Vancouver, Canada, 2018.

Mehra, B., \& Singh, V. (2014). Recruitment and retention in the Information Technology Rural Librarian Master's Scholarship Program (Part I and Part II): Implications of social justice in the Southern and Central Appalachian Region. Qualitative and Quantitative Methods in Libraries Journal, Special Issue 2014: Social Justice, Social Inclusion, 13-22.

Mehra, B.,\& Singh, V. (2017). Library leadership-in-training as embedded change agents to further social justice in rural communities: Teaching of library management subjects in the ITRL and ITRL2. In N. A. Cooke \& M. E. Sweeney (Eds.), Teaching for justice: Implementing social justice in the LIS classroom (pp. 247-286). Sacramento, CA: Library Juice Press.

Mehra, B., Singh, V., Hollenbach, N., \& Partee II, R. P. (2017). Rural librarians as change agents in the $21^{\text {st }}$ century: Applying community informatics in the Southern and Central Appalachian Region to further ICT literacy training. In B.Real (Ed.), Rural and small public libraries: Challenges and opportunities (Advances in Librarianship, 43) (pp.123153). Bingley, UK: Emerald Group Publishing. https://doi.org/10.1108/S0065$\underline{283020170000043006}$

Mehra, B., Singh, V., \& Sikes, E. S. (2018, February). Assessment of rural library professionals' role in community engagement in the Southern and Central Appalachian Region: Mobilization from change agents to community anchors (CA2CA@SCA-RL) (Works-InProgress Poster). Association for Library and Information Science Education (ALISE) Annual Conference: The expanding LIS education universe, Denver, Colorado, February 6-9, 2018.

Moraga, C., \& Anzaldúa, G. (2015). This bridge called my back: Writings by radical women of color (4th ed.). Albany, NY: SUNY Press.

Oelschlegel, S., Earl, M., Taylor, M., \& Muenchen, R. (2009). Health information disparities? Determining the relationship between age, poverty, and rate of calls to a consumer and patient health information service. Journal of the Medical Library Association, 97(3), 225-227. https: //dx.doi.org/10.3163\%2F1536-5050.97.3.013

Office of Management and Budget. (1998, December 21). Part III alternative approaches to defining metropolitan and nonmetropolitan areas. Federal Register, 63 (637052670561). Retrieved from https://clintonwhitehouse5.archives.gov/textonly/OMB/fedreg/msa.html

Page, M., \& Scott, A. (2001). Change agency and women's learning new practices in community informatics. Information, Communication \& Society, 4(4), 528-559. https://doi.org/10.1080/13691180110097003

Patton, M.Q. (1990). Qualitative evaluation and research methods. Newbury Park, CA: Sage. PDA. Inc., The Cecil G. Sheps Center for Health Services Research, and the Appalachian 
Regional Commission. (2017). Creating a culture of health in Appalachia: Disparities and bright spots. Health Disparities in Appalachia. Retrieved from https://www.arc.gov/assets/research_reports/Health_Disparities_in_Appalachia_Augus t_2017.pdf

Prechtel, K. (2008). The health reference interview: Getting to the heart of the question while assessing your customer's literacy skills. In M. Kars, L. M. Baker, \& F. L. Wilson (Eds.), The Medical Library Association guide to health literacy (pp. 181-196). New York, NY: Neal Schuman.

Rathge, R. W. (1997). Rural demography. In G. A. Goreham (Ed.), Encyclopedia of rural America: The land and the people. Santa Barbara, CA: ABC-CLIO.

Real, B., Bertot, J. C., \& Jaeger, P. T. (2014). Rural public libraries and digital inclusion: Issues and challenges. Information Technology and Libraries, 33(1), 6-24.

https://doi.org/10.6017/ital.v33i1.5141

Real, B., McDermott, A., Bertot, J., \& Jaeger, P. (2015). Digital inclusion and the Affordable Care Act: Public libraries, politics, policy, and enrollment in "Obamacare". Public Library Quarterly, 34(1), 1-22. https://doi.org/10.1080/01616846.2015.1000770

Real, B., \& Rose, R. N. (2017). Rural libraries in the United States: Recent strides, future possibilities, and meeting community needs. Chicago, IL: American Library Association. Retrieved from

http://www.ala.org/advocacy/sites/ala.org.advocacy/files/content/pdfs/Rural\%20pap er\%2007-31-2017.pdf

Rubenstein, E. (2012). From social hygiene to consumer health: Libraries, health information, and the American public from the late nineteenth century to the 1980s. Library \& Information History, 28(3), 202-219. https://doi.org/10.1179/1758348912Z.00000000016

Rubenstein, E. (2016a). Breaking health barriers: How can public libraries contribute? Public Library Quarterly, 35(4), 331-337. https://doi.org/10.1080/01616846.2016.1245006

Rubenstein, E. (2016b). Health information and health literacy: Public library practices, challenges, and opportunities. Public Library Quarterly, 35(1), 49-71. https://doi.org/10.1002/pra2.2015.1450520100140

Rubenstein, E. L. (2017). "I didn't learn that in library school"- Experiential learning in consumer health for future public librarians. Library Trends, 66(1), 37-51. http://dx.doi.org/10.1353/lib.2017.0027

Singh, G., Kogan, M., \& Slifkin, R. (2017). Widening disparities in infant mortality and life expectancy between Appalachia and the rest of the United States, 1990-2013. Health Affairs, 36(8), 1423-1432. https://doi.org/10.1377/hlthaff.2016.1571

Stanton, D. (2017, December 20). Dare I ask? Consumer health in a rural library setting. Public Libraries Online: News \& Opinion. Retrieved from http: //publiclibrariesonline.org/2017/12/dare-i-ask-consumer-health-in-a-rural-

The International Journal of Information, Diversity, \& Inclusion, 3(3), 2019

ISSN 2574-3430, jps.library.utoronto.ca/index.php/ijidi/index

DOI: $10.33137 /$ ijidi.v3i3.32963 


\section{library-setting/}

Swan, D. W., Grimes, J., \& Owens, T. (2013). The state of small and rural libraries in the United States. Washington, DC: Institute of Museum and Library Services. Retrieved from https://www.imls.gov/assets/1/AssetManager/Brief2013_05.pdf

Temple, K. M. (2017, May 3). Rural health literacy: Who's delivering health information? The Rural Monitor. Retrieved from https: / /www.ruralhealthinfo.org/ruralmonitor/delivering-health-information/

U. S. Census Bureau. (2010). 2010 Census Urban Area facts. U.S. Department of Commerce. Retrieved, from https://www.census.gov/geo/reference/ua/uafacts.html

U.S. Census Bureau. (2012, December 6). 2007-2011 American Community Survey. Census Bureau releases American Community Survey estimates, most detailed portrait of every U.S. community (Newsroom Archive: Press Release). Retrieved from https://www.census.gov/newsroom/releases/archives/american_community_survey_a cs/cb12-228.html

U. S. Environmental Protection Agency. (2017). Livable communities in Appalachia. Washington, DC: U. S. Environmental Protection Agency. Retrieved from https://www.epa.gov/smartgrowth/livable-communities-appalachia

Williams, J. A. (2003). Appalachia: A history. Chapel Hill, NC: The University of North Carolina Press.

Woodson, D., Timm, D., \& Jones, D. (2011). Teaching kids about healthy lifestyles through stories and games: Partnering with public libraries to reach local children. Journal of Hospital Librarianship, 11(1), 59-69. https://doi.org/10.1080/15323269.2011.538619

Zickuhr, K. \& Smith, A. (2012). Digital differences. Washington, DC: Pew Research Center. Retrieved from https: //www. pewinternet.org/2012/04/13/digital-differences/

Zionts, N., Apter, J., Kuchta, J., \& Greenhouse, P. (2010). Promoting consumer health literacy: Creation of a health information librarian fellowship. Reference \& User Services Quarterly, 49(4), 350-359.

Zoom Video Communications, Inc. (2019). About Zoom. Retrieved, from https://zoom. us/about

Bharat Mehra (bmehra@ua.edu) joined the School of Library and Information Studies at the University of Alabama as professor and EBSCO Endowed Chair in Social Justice in January 2019. From January 2005 - December 2018 he was a faculty member in the School of Information Sciences at the University of Tennessee-Knoxville. His research focuses on diversity and social justice in library and information science and community informatics or the use of information and communication technologies to empower minority and underserved populations to make meaningful changes in their everyday lives. He has applied action research to further engaged scholarship and community engagement while collaborating with racial/ethnic groups, international diaspora, sexual minorities, rural communities, low-income families, small

The International Journal of Information, Diversity, \& Inclusion, 3(3), 2019

ISSN 2574-3430, jps.library.utoronto.ca/index.php/ijidi/index

DOI: $10.33137 /$ ijidi.v3i3.32963 
businesses, and others, to represent their experiences and perspectives in the design of community-based information systems and services. Mehra primarily teaches courses on public library management, collection development, resources and services for adults, diversity services in libraries, and grant development for information professionals.

Everette Scott Sikes (esikes@vols.utk.edu) is a doctoral student in the School of Information Sciences at the University of Tennessee-Knoxville. He also serves as the associate director of the Appalachian Center for Civic Life and Instructor in the Civic Innovation program at Emory \& Henry College. A native of the Appalachian region, his research interests focus on the role of information organizations in rural areas and their importance to the civic and social life of communities.

Vandana Singh (vandana@utk.edu) is associate professor in the School of Information Sciences at the University of Tennessee-Knoxville. Her research interest areas are the use of information technology for learning in workplaces as well in distance education, Computer Supported Cooperative Work, Human Computer Interaction and Information Systems. Singh has received multiple research grants from federal agencies, including National Science Foundation (NSF), Institute of Museum and Library Services (IMLS) and United States Geological Society (USGS). Her work has been published and recognized in national and international conferences and journals.

The International Journal of Information, Diversity, \& Inclusion, 3(3), 2019

ISSN 2574-3430, jps. library.utoronto.ca/index.php/ijidi/index

DOI: $10.33137 /$ ijidi.v3i3.32963 